\title{
Oxygen inhibition of nitrogenase activity in Klebsiella pneumoniae
}

\author{
Eugene P. Kavanagh* and Susan Hill \\ AFRC Institute of Plant Science Research, Nitrogen Fixation Laboratory, University of Sussex, \\ Brighton BN1 9RQ, UK
}

(Received 26 October 1992; revised 18 January 1993; accepted 26 February 1993)

\begin{abstract}
A purpose-built oxystat has been used to study reversible inhibition of nitrogenase by $\mathrm{O}_{2}$ in the facultative anaerobe Klebsiella pneumoniae. $\mathrm{C}_{2} \mathrm{H}_{2}$-reducing activity in samples from either an anaerobic glucose-limited or an $\mathrm{O}_{2}$ limited diazotrophic chemostat culture was completely inhibited by exposure to a dissolved $\mathrm{O}_{2}$ concentration (DOC) of $1.5 \mu \mathrm{M}$ or above. Subsequently, under anaerobic conditions, $\mathrm{C}_{2} \mathrm{H}_{2}$-reducing activity returned in the absence of de novo protein synthesis. The amount of activity returning never reached $100 \%$ of the initial anaerobic activity before $\mathrm{O}_{2}$ treatment. The degree of reversibility was inversely proportional to the log of DOC during exposure and was decreased by increasing the time of exposure to $\mathrm{O}_{2}$ (about $60 \%$ reversibility occurred after a 20 min exposure to $6 \mu \mathrm{M}-\mathrm{O}_{2}$ ). The failure to obtain complete recovery of activity was apparently not due to inactivation of the very $\mathrm{O}_{2}$-sensitive pyruvate-flavodoxin oxidoreductase (nifJ product) which provides electrons for nitrogenase activity in vivo. Samples from the $\mathrm{O}_{2}$-limited culture behaved similarly to those limited by glucose. Thus, 'training' of the organism to use $\mathrm{O}_{2}$ during growth does not influence the tolerance of nitrogenase to $\mathrm{O}_{2}$. Since the behaviour towards $\mathrm{O}_{2}$ reported here for $K$. pneumoniae differs from that known to occur in Azotobacter, the mechanism of protection of nitrogenase from $\mathrm{O}_{2}$ damage may differ in these organisms.
\end{abstract}

\section{Introduction}

Nitrogenase, the enzyme responsible for the reduction of $\mathrm{N}_{2}$ to $\mathrm{NH}_{3}$, comprises two redox proteins, both of which are irreversibly damaged by $\mathrm{O}_{2}$ (Robson \& Postgate, 1980). Therefore nitrogenase can only function under anaerobic conditions. In obligately aerobic Azotobacter spp. $\mathrm{O}_{2}$ is excluded from the active site of nitrogen fixation by protective processes. These processes include respiratory and conformational protection which were first characterized in A. chroococcum (Drozd \& Postgate, 1970; Robson \& Postgate, 1980). Respiratory activity in Azotobacter spp. prevents the access of $\mathrm{O}_{2}$ to the $\mathrm{O}_{2}-$ sensitive site of nitrogenase. The respiratory rate in Azotobacter spp. can adjust to a change in the rate of $\mathrm{O}_{2}$ supply, thus maintaining protection of the $\mathrm{O}_{2}$-sensitive sites. An increase in the supply of $\mathrm{O}_{2}$ to Azotobacter spp. during growth causes an increase in the respiratory rate and in the optimum dissolved $\mathrm{O}_{2}$ concentration (DOC) for nitrogenase activity. An increase in the $\mathrm{O}_{2}$ supply also

*Author for correspondence. Tel. 0273 678242; fax 0273678133 ; e-mail Hill@UK.ac.afrc.nfl.

Abbreviation: DOC, dissolved oxygen concentration. causes an increase in the $d$-type cytochrome oxidase content, which is essential for aerotolerant nitrogenase activity in $A$. vinelandii (Kelly et al., 1990).

However, when the level of $\mathrm{O}_{2}$ supplied to a culture of Azotobacter spp. is greater than that consumed via respiration, nitrogenase activity is inhibited. The inhibition arises from the binding of the two $\mathrm{O}_{2}$-sensitive proteins of nitrogenase to the $\mathrm{Fe}-\mathrm{S}$ protein II (called the Shethna or protective protein) to form an $\mathrm{O}_{2}$-tolerant complex (Scherings et al., 1977). The inhibition is reversible, provided that the subsequent $\mathrm{O}_{2}$ supplied to the culture is lowered to a level which can be consumed via respiration (Drozd \& Postgate, 1970). The degree of reversibility of inhibition is not influenced by either the DOC causing inhibition or the duration of exposure to $\mathrm{O}_{2}$ (Dingler \& Oelze, 1985).

Hill (1976a) reported a tolerance of nitrogenase activity to $\mathrm{O}_{2}$ in the anaerobically grown facultative anaerobe Klebsiella pneumoniae. This tolerance increased when the organism was grown in the presence of $\mathrm{O}_{2}$. Additionally Hill et al. (1984) and Kavanagh \& Hill (1990) reported an optimum DOC for nitrogenase activity in $K$. pneumoniae of $0.03 \mu \mathrm{M}$, which is near the apparent $K_{\mathrm{m}}$ for $\mathrm{O}_{2}(0.02 \mu \mathrm{M})$ of the $d$-type cytochrome oxidase (the only oxidase detected during anaerobic or 
micro-aerobic nitrogen fixation in K. pneumoniae; Smith et al., 1990). The functions of the $d$-type cytochrome oxidase in $K$. pneumoniae are to support energy-requiring processes and to protect anaerobic processes from $\mathrm{O}_{2}$ (Hill et al., 1990).

Complete inhibition of nitrogenase activity in $K$. pneumoniae occurs during exposure to a DOC greater than $0.55 \mu \mathrm{M}-\mathrm{O}_{2}$ (Hill et al., 1984). Earlier work by Hill (1976a) suggested that, in $K$. pneumoniae, the complete inhibition of nitrogenase activity by $\mathrm{O}_{2}$ was reversible upon the removal of $\mathrm{O}_{2}$. This implied the operation of a protective mechanism against $\mathrm{O}_{2}$ damage to nitrogenase in $K$. pneumoniae similar to that in Azotobacter. However, since in these experiments the DOC within the assay system was neither measured nor maintained, Hill's evidence was not conclusive. To extend investigations into the reversibility of $\mathrm{O}_{2}$ inhibition of nitrogenase activity in $K$. pneumoniae, particularly with regard to similarities of the protective mechanism to that in Azotobacter, we have developed an oxystat designed to maintain DOCs which are inhibitory to nitrogenase activity ( $>0.55 \mu \mathrm{M} \mathrm{O}_{2} ;$ Hill et al., 1984). The requirement to measure DOCs over a range greatly in excess of $0.55 \mu \mathrm{M}-\mathrm{O}_{2}$ excluded the use of the $\mathrm{O}_{2}$-sensing systems employing leghaemoglobin (Bergersen \& Turner, 1979) or photobacteria (Kavanagh \& Hill, 1990) since these systems are only functional within a DOC range of 0.003-1 $\mu \mathrm{M}$. Therefore a galvanic electrode with a functional range of 1.5-1200 $\mu \mathrm{M}-\mathrm{O}_{2}$ was used. In samples from chemostat cultures similar to those used by Hill (1976a), we confirm that, as in Azotobacter, inhibition of nitrogenase activity by $\mathrm{O}_{2}$ is reversible. But, unlike the situation in Azotobacter, the amount of activity returning is never $100 \%$ and is dependent upon the DOC causing inhibition and the duration of exposure to $\mathrm{O}_{2}$. We also show that, in $K$. pneumoniae, the system donating electrons to nitrogenase in vivo is not more $\mathrm{O}_{2}$-sensitive than nitrogenase itself.

\section{Methods}

Organism and culture. Klebsiella pneumoniae strain M5a1 was maintained on nutrient agar slopes in air at $20^{\circ} \mathrm{C}$ and subcultured monthly. The chemostat apparatus and the procedures for establishing and maintaining anaerobic glucose-limited $\mathrm{N}_{2}$-fixing and $\mathrm{O}_{2}$-limited $\mathrm{N}_{2}$-fixing chemostat populations have been described previously (Hill, $1976 a$ ). The medium was that of Hill (1976a) except that nitrilotriacetic acid $(300 \mu \mathrm{M})$, which is not a nitrogen source for $K$. pneumoniae, was included as an iron chelator, and $p$-aminobenzoic acid and biotin were omitted (Hill, 1976b). The steady states were grown at $D=0 \cdot 1 \mathrm{~h}^{-1}$ and at $30^{\circ} \mathrm{C}$. The biomasses for the steady-state anaerobic glucose-limited and $\mathrm{O}_{2}$-limited populations were $230 \pm 10$ and $300 \pm 10 \mu \mathrm{g}$ protein $\mathrm{ml}^{-1}$ respectively (means $\pm \mathrm{SD}$ ). The anaerobic specific $\mathrm{C}_{2} \mathrm{H}_{2}$-reducing activity in samples from either culture was $62 \pm 2.0 \mathrm{nmol} \mathrm{C}_{2} \mathrm{H}_{4}(\mathrm{mg} \text { protein })^{-1}$ $\mathrm{min}^{-1}$ when estimated in flasks, as described previously (Hill, 1976a), or during the first anaerobic phase of an oxystat experiment (Fig. 2).
The oxystat. The oxystat (Fig. 1) was designed to maintain predetermined values of DOC in samples of liquid culture taken from a chemostat. These values ranged from the limit of stable detection of DOC by the oxygen electrode (typically $1.5 \mu \mathrm{M}$ ) to $\mathrm{O}_{2}$ saturation $(1200 \mu \mathrm{M})$. Maintenance of the desired DOC $( \pm 5 \%)$ was achieved by the continual correction of stirrer speed.

The double-walled glass reaction vessel (approximately $86 \mathrm{ml}$ ), fitted with a ground-glass socket (SRB34, Quickfit) was closed by a groundglass cone carrying a threaded plastic top. The $\mathrm{O}_{2}$ electrode and two narrow steel tubes ( $1 \mathrm{~mm}$ internal diameter) were passed through the opening in the plastic top and were held in position with quick-setting silicon rubber (Dow Corning), which filled the inside of the cone. An injection head ( $1 \mathrm{~mm}$ internal diameter, Pye Unicam) was mounted on top of one tube, which provided the injection port (A in Fig. 1), and a venting non-return valve (Fisons) was mounted on top of the other (B in Fig. 1). The vessel carried a magnetic flea, and was maintained at $30^{\circ} \mathrm{C}$ by pumping water from a thermostatically controlled water bath between the two glass walls of the vessel. An identical vessel fitted with a dummy $\mathrm{O}_{2}$ electrode was used for the anaerobic control treatment (see Fig. 1).

The sterilizable galvanic $\mathrm{O}_{2}$ electrode ( $\mathrm{C}$ in Fig. 1) was based on the design of Johnson et al. (1964). The cathode and anode were contained in a bent Pyrex glass tube to ensure that the membrane-covered tip was always immersed within the liquid contained in the reaction vessel whilst not obstructing the magnetic flea. The surface of the electrolyte was continually flushed with a slow stream of $\mathrm{N}_{2}$.

The $\mathrm{O}_{2}$ electrode was calibrated in $20 \mathrm{ml}$ of spent medium which was recovered by passing a chemostat culture sample through a cellulose acetate membrane filter $(0.45 \mu \mathrm{m}$ pore size, Sartorius Instruments). A range of DOCs was obtained by sparging the stirred medium with the appropriate gas mixtures $\left(\mathrm{N}_{2}+\right.$ air or $\left.\mathrm{O}_{2}\right)$. A linear response by the electrode was obtained from 1.5 to $1200 \mu \mathrm{M}-\mathrm{O}_{2}$. At the end of each experiment the calibration was checked.

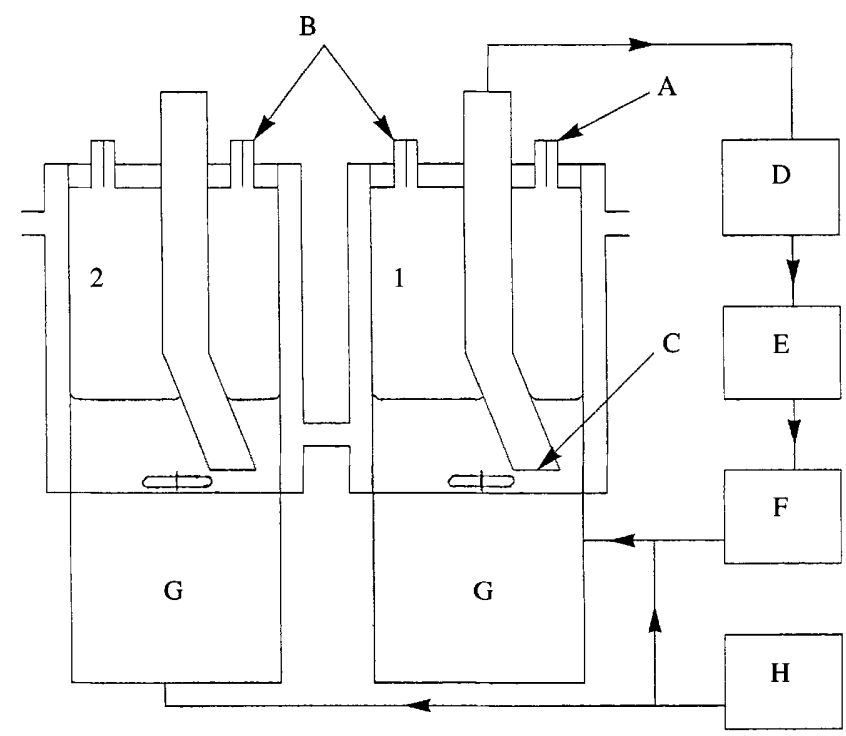

Fig. 1. Apparatus for the exposure of bacterial suspensions to anaerobic conditions or to maintained DOC. The DOC was measured and maintained within a culture in the vessel labelled 1 whilst an anaerobic culture was run simultaneously in the vessel labelled 2 . The components of the oxystat, control vessel and dissolved oxygen control apparatus are indicated as follows: A, injection port for the introduction of liquids and gases; $\mathrm{B}$, venting valve; $\mathrm{C}$, membrane-covered $\mathrm{O}_{2}$ electrode; $\mathrm{D}$, amplifier; $\mathrm{E}$, indicator/controller; $\mathrm{F}$, feedback thyristor controller; $\mathrm{G}$, magnetic stirrers; $\mathrm{H}$, multi-turn potentiometer. 
The current generated by the $\mathrm{O}_{2}$ electrode was attenuated with a variable resistance $(0-1 \mathrm{k} \Omega)$ in order to improve the signal-to-noise ratio required for the control of DOC. The electrode output (typically $10 \mu \mathrm{A}$ for air-saturated water at $30^{\circ} \mathrm{C}$ ), was amplified by a multi-range $\mathrm{O}_{2}$ meter (model FL3, Western Biological; D in Fig. 1), which also displayed the DOC in analogue form and transformed the signal into a $\mathrm{mV}(0-100)$ output. This variable $\mathrm{mV}$ output was recorded on a multi-range chart recorder (model S35-922/150, Griffin Nesco) and was fed to a Clearspan indicator controller (model P130L, Kent Industrial Measurements; $\mathrm{E}$ in Fig. 1). The controller compares a preset voltage, related to the maintained DOC required, with the incoming voltage, and the difference activates relay circuits. Their rate of response to yield the $0-10 \mathrm{~mA}$ output was set to minimize hunting. This setting is dependent upon the relationship between the maintained DOC, the $\mathrm{O}_{2}$ concentration of the gas phase, and the $\mathrm{O}_{2}$ demand of the culture. The resultant variable output $(0-10 \mathrm{~mA})$ was fed into a $\mathrm{AC}$ thyristor controller (model MAC240-10-8, United Automation; F in Fig. 1) which in turn processed the incoming signal to provide the current to drive a magnetic stirrer (Rank Bros.; G in Fig. 1) at a speed sufficient to maintain the required DOC. The original single-turn potentiometer incorporated in the stirrer speed control was replaced by a potentiometer ( $250 \Omega 10$ turn; H in Fig. 1) which allowed fine manual control.

Supplies of $\mathrm{N}_{2}, \mathrm{O}_{2}$ and air were carried in hard nylon tubing $(3.2 \mathrm{~mm}$ external diameter, $1.6 \mathrm{~mm}$ internal diameter, Phase Separation). Their fluxes were measured by either rotameters (Rotameter) or meterates (Meterates) and were modified by precision gas-flow controllers (Negretti \& Zambra Aviation). The gases were passed through $\mathrm{H}_{2} \mathrm{O}$ contained in dreschel bottles $(250 \mathrm{ml})$ before they were introduced into the reaction vessel via stainless steel hypodermic needles that pierced the sampling port.

Inhibition of protein synthesis by antibiotics. In the earlier work of Hill (1976a) chloramphenicol was assumed to inhibit protein synthesis because it had prevented the derepression of nitrogenase activity in $K$. pneumoniae (Tubb \& Postgate, 1973). Chloramphenicol and several other antibiotics were tested for their ability to inhibit de novo protein synthesis without inhibiting nitrogenase activity. The incorporation of ${ }^{14} \mathrm{C}$-labelled amino acids into trichloroacetic-acid-precipitable polypeptides was used to measure protein synthesis. Samples $(20 \mathrm{ml})$ of a glucose-limited anaerobic $\mathrm{N}_{2}$-fixing population were transferred in $\mathrm{N}_{2^{-}}$ flushed syringes to two $\mathrm{N}_{2}$-sparged reaction vessels of the design described above for the anaerobic control treatment. Both vessels were maintained at $30^{\circ} \mathrm{C}$ and contained $60 \mathrm{~mm}$-glucose (final concentration). One vessel also contained the antibiotic to be tested. Immediately after the injection of the culture, $\mathrm{C}_{2} \mathrm{H}_{2}(10 \mathrm{ml})$ was injected into both vessels, and a sample $(1 \mathrm{ml})$ of the culture was removed from each vessel initially and at the end of the incubation period to measure the rate of protein synthesis. Gas samples $(0.5 \mathrm{ml})$ were taken at $5 \mathrm{~min}$ intervals during incubation for analysis of $\mathrm{C}_{2} \mathrm{H}_{2}$ and $\mathrm{C}_{2} \mathrm{H}_{4}$ by gas chromatography (Hill et al., 1984). The rate of protein synthesis was measured by estimating the incorporation of ${ }^{14} \mathrm{C}$-labelled amino acids into polypeptides after injecting the culture sample $(1 \mathrm{ml})$ into a $\mathrm{N}_{2}$-flushed capped (Subaseal closure) polycarbonate tube $(10 \mathrm{ml}$, Nunc), containing $0.1 \mathrm{ml}$ of $1.3 \mathrm{~mm}^{-14} \mathrm{C}$-labelled Casamino acids $(9.25 \mathrm{kBq}$ in $0.1 \mathrm{ml}$; Amersham). After $10 \mathrm{~min}$ agitation at $30^{\circ} \mathrm{C}$ the assay was terminated by injecting $0.05 \mathrm{ml}$ vitamin-free Casamino acids $\left(10 \mathrm{mg} \mathrm{ml}^{-1}\right.$; Difco). The organisms were harvested by centrifugation $(15 \mathrm{~min}$ at $5000 \mathrm{~g})$ and washed once in saline phosphate buffer (Cannon, 1980), containing vitamin-free Casamino acids $\left(1 \mathrm{mg} \mathrm{ml}^{-1}\right)$. The organisms were then resuspended in Laemmli double-strength sample buffer $(40 \mu \mathrm{l})$ and disrupted by heating for $5 \mathrm{~min}$ in a boiling water bath (Cannon, 1980). Aliquots $(5 \mu \mathrm{l})$ of the supernatant obtained following centrifugation for $15 \mathrm{~min}$ at $5000 \mathrm{~g}$ were spotted onto Whatman no. 1 paper and the total polypeptide synthesis was measured as the incorporation of radioactivity into trichloroacetic-acid-precipitable material as described by Cannon et al. (1985). At the concentration of chloramphenicol $\left(100 \mu \mathrm{g} \mathrm{ml}^{-1}\right)$ used by Hill (1976a), the incorporation of ${ }^{14} \mathrm{C}$-labelled amino acids was inhibited by only $59 \%$ within $30 \mathrm{~s}$, and by $90 \%$ after $30 \mathrm{~min}$. Increasing the concentration of chloramphenicol fivefold had little effect (Table 1). Therefore five other antibiotics, kanamycin, gentamicin, streptomycin $\left(50,75 \mu \mathrm{g} \mathrm{ml}^{-1}\right)$, erythromycin $\left(50,500 \mu \mathrm{g} \mathrm{ml}^{-1}\right)$ and tetracycline $\left(20-200 \mu \mathrm{g} \mathrm{ml}^{-1}\right)$ were tested under the conditions described for chloramphenicol. Erythromycin and kanamycin failed to inhibit protein synthesis. Gentamicin inhibited protein synthesis but, like streptomycin, also inhibited the specific $\mathrm{C}_{2} \mathrm{H}_{2}$-reducing activity by about $20 \%$. However, tetracycline immediately and completely inhibited protein synthesis. Concentrations greater than $100 \mu \mathrm{g} \mathrm{ml}^{-1}$ also decreased the specific $\mathrm{C}_{2} \mathrm{H}_{2}$-reducing activity (see Table 1). The lowest concentration of tetracycline which immediately and completely inhibited protein synthesis was $20 \mu \mathrm{g} \mathrm{ml}^{-1}$ (see Table 1); therefore the concentration routinely used to prevent de novo synthesis of nitrogenase in all experiments described below was $40 \mu \mathrm{g} \mathrm{ml}^{-1}$.

Procedures for exposing samples to controlled DOC and to anaerobiosis for the measurement of nitrogenase $\left(\mathrm{C}_{2} \mathrm{H}_{2}\right.$-reducing $)$ activity during and after $\mathrm{O}_{2}$ treatment. Equal aliquots of culture ( 20 or $30 \mathrm{ml}$; the larger volume was used for the preparation of leaky cells) were removed in $\mathrm{N}_{2}$-flushed syringes from the chemostat and injected into the oxystat and control vessels (at A in Fig. 2). Both vessels contained tetracycline and, when required, glucose in $1.1 \mathrm{ml}$ of distilled water to give final concentrations of $40 \mu \mathrm{g} \mathrm{ml}^{-1}$ and $60 \mathrm{~mm}$ respectively, and were flushed with $\mathrm{N}_{2}\left(200 \mathrm{ml} \mathrm{min}^{-1}\right)$ for $10 \mathrm{~min}$ prior to the injection of the culture sample. The stirrers were switched on and sparging was continued for 5 min with the $\mathrm{N}_{2}$ flowing ( $400 \mathrm{ml} \mathrm{min}^{-1}$ ) through the culture. Upon removal of the $\mathrm{N}_{2}$ supply, $10 \mathrm{ml} \mathrm{C}_{2} \mathrm{H}_{2}$ was injected into both vessels (B in Fig. 2). Due to the high solubility of $\mathrm{C}_{2} \mathrm{H}_{2}$ in the stirred culture sample this injection did not activate the venting valve. Over the following $20 \mathrm{~min}$, at approximately $5 \mathrm{~min}$ intervals, $0.5 \mathrm{ml} \mathrm{N} \mathrm{N}_{2}$ was injected into the gas phase, and $0.5 \mathrm{ml}$ of a gas sample was removed for analysis of $\mathrm{C}_{2} \mathrm{H}_{4}$ and $\mathrm{C}_{2} \mathrm{H}_{2}$. Both vessels were then sparged for $7 \mathrm{~min}$ with $\mathrm{N}_{2}\left(400 \mathrm{ml} \mathrm{min}^{-1}\right)$ to drive out $\mathrm{C}_{2} \mathrm{H}_{4}$ and $\mathrm{C}_{2} \mathrm{H}_{2}$ (C to D in Fig. 2). The stirrers were turned off and the $\mathrm{N}_{2}$ supply to the oxystat vessel was replaced by an air or $\mathrm{O}_{2}$ supply ( $\mathrm{E}$ in Fig. 2). This supply was maintained for a predetermined time (estimated by trial and error) in order to provide sufficient $\mathrm{O}_{2}$ to maintain the desired DOC (Fig. 2). After the removal of the gas supplies, the stirrer and the oxystat control mechanism were switched on. As soon as the desired DOC had been reached, $10 \mathrm{ml} \mathrm{C}_{2} \mathrm{H}_{2}$ was injected into each vessel ( $\mathrm{F}$ in Fig. 2) and $0.5 \mathrm{ml}$ gas samples were taken for analysis at approximately $5 \mathrm{~min}$ intervals. After $\mathrm{O}_{2}$ exposure, the cultures were sparged with $\mathrm{N}_{2}$ $\left(400 \mathrm{ml} \mathrm{min}^{-1}\right)$ until the DOC had returned to zero (G to $\mathrm{H}$ in Fig. 2), when $10 \mathrm{ml}$ of $\mathrm{C}_{2} \mathrm{H}_{2}$ was injected into each vessel, and samples were taken for analysis of $\mathrm{C}_{2} \mathrm{H}_{4}$ and $\mathrm{C}_{2} \mathrm{H}_{2}$ at $10 \mathrm{~min}$ intervals over the following $60 \mathrm{~min}$. The effect of $\mathrm{O}_{2}$ treatment in the absence of glucose was investigated by injecting $60 \mathrm{~mm}$-glucose into both vessels $(\mathrm{H}$ in Fig. 2) following the exposure of the culture sample to the desired DOC. No $\mathrm{C}_{2} \mathrm{H}_{2}$-reducing activity was detected in either vessel until glucose was added. The anaerobic specific activity of glucose-limited chemostat samples in the presence of glucose was measured both in the control vessel and in $7 \mathrm{ml}$ assay bottles. The bottles, capped with a Subaseal closure, were shaken for $1 \mathrm{~h}$ at $30^{\circ} \mathrm{C}$ and contained in $1 \mathrm{ml}$ culture sample, $60 \mathrm{~mm}$-glucose and $10 \% \mathrm{C}_{2} \mathrm{H}_{2}$ in Ar. The specific activities were the same in both vessels. The concentration of glucose remaining following all experiments was at least $30 \mathrm{~mm}$.

Preparing and assaying leaky cells. Samples of $20 \mathrm{ml}$ were removed from the oxystat and from the control vessels in $\mathrm{N}_{2}$-flushed syringes (at the time indicated between $\mathrm{G}$ and $\mathrm{H}$ in Fig. 2) and were then injected into $\mathrm{N}_{2}$-flushed plastic universal bottles which were capped with 
Table 1. Effect of antibiotics on anaerobic protein synthesis and the specific nitrogenase activity in K. pneumoniae

\begin{tabular}{|c|c|c|c|c|}
\hline \multirow[b]{2}{*}{ Antibiotic } & \multirow{2}{*}{$\begin{array}{c}\text { Antibiotic } \\
\text { concn } \\
\left(\mu \mathrm{g} \mathrm{ml}^{-1}\right)\end{array}$} & \multicolumn{2}{|c|}{$\begin{array}{l}\text { Percentage incorporation* of } \\
{ }^{14} \mathrm{C} \text {-labelled amino acids following } \\
\text { exposure to antibiotic for: }\end{array}$} & \multirow{2}{*}{$\begin{array}{c}\text { Specific activity } \\
{\left[\text { nmol } \mathrm{C}_{2} \mathrm{H}_{4}\right.} \\
\text { (mg protein })^{-1} \mathrm{~min}^{-1} \text { ) }\end{array}$} \\
\hline & & $<0.5 \mathrm{~min}$ & $30 \mathrm{~min}$ & \\
\hline Chloramphenicol & $\begin{array}{r}0 \\
50 \\
100 \\
200 \\
500\end{array}$ & $\begin{array}{l}100 \cdot 0 \pm 3 \cdot 0 \\
64 \cdot 0 \\
41 \cdot 0 \\
13 \cdot 2 \\
8 \cdot 2\end{array}$ & $\begin{array}{l}74 \cdot 0 \pm 5 \cdot 0(3) \\
12 \cdot 4(1) \\
9 \cdot 9(1) \\
7 \cdot 2(1) \\
6 \cdot 6(1)\end{array}$ & $\begin{array}{c}61 \cdot 8 \pm 2 \cdot 0 \\
61 \cdot 8 \pm 2 \cdot 0 \\
61 \cdot 8 \pm 2 \cdot 0 \\
\text { ND } \\
\text { ND }\end{array}$ \\
\hline Tetracycline & $\begin{array}{r}0 \\
20 \\
40 \\
50 \\
100 \\
150 \\
200\end{array}$ & $\begin{array}{c}100 \cdot 0 \pm 2 \cdot 0 \\
0 \cdot 6 \pm 0 \cdot 3 \\
0 \cdot 2 \pm 0 \cdot 1 \\
0 \cdot 2 \pm 0 \cdot 05 \\
0 \cdot 2 \pm 0 \cdot 1 \\
0 \cdot 2 \pm 0 \cdot 1 \\
0 \cdot 2 \pm 0 \cdot 1\end{array}$ & $\begin{array}{c}76.0 \pm 2.0(5) \\
0.5 \pm 0.2(2) \\
0.2 \pm 0.05(3) \\
0.2 \pm 0.05(3) \\
0.2 \pm 0.05(2) \\
0.2 \pm 0.06(2) \\
0.2 \pm 0.1(2)\end{array}$ & $\begin{array}{l}61 \cdot 8 \pm 2 \cdot 0 \\
61 \cdot 8 \pm 2 \cdot 0 \\
61 \cdot 8 \pm 2 \cdot 0 \\
61 \cdot 0 \pm 2 \cdot 0 \\
61 \cdot 0 \pm 2 \cdot 0 \\
57 \cdot 0 \pm 2 \cdot 0 \\
51 \cdot 0 \pm 3 \cdot 0\end{array}$ \\
\hline
\end{tabular}

ND, Not determined.

* Percentage incorporation into polypeptides $=[(\beta$ emission with antibiotic $) /(\beta$ emission of control $)] \times 100$, where $\beta$ emission of control $(100 \%)=110000 \pm 1000$ c.p.m. (mean \pm sD). Figures in parentheses indicate the number of different assays.

Subaseal closures. The organisms were harvested by centrifugation ( $3000 \mathrm{~g}$ for $15 \mathrm{~min}$ at $4{ }^{\circ} \mathrm{C}$ ) and resuspended in $1 \mathrm{ml} \mathrm{N}$-sparged $25 \mathrm{mM}$ HEPES pH 7.6 containing $20 \mathrm{~mm}-\mathrm{NaCl}, 100 \mu \mathrm{g}$ dithiothreitol and $2 \%$ $(\mathrm{v} / \mathrm{v})$ Triton $\mathrm{X}-100$. The mixture was incubated with occasional shaking for $1 \mathrm{~h}$ at room temperature. Duplicate $0.2 \mathrm{ml}$ samples of the mixture were then injected into $7 \mathrm{ml}$ assay bottles capped with Subaseal closures and containing $33 \mathrm{~mm}-\mathrm{Tris} / \mathrm{HCl} \mathrm{pH} \mathrm{8.0,} 5.3 \mathrm{~mm}-\mathrm{ATP}$, $13.3 \mathrm{~mm}-\mathrm{MgCl}_{2}, 26.7 \mathrm{~mm}$-creatine phosphate, $50 \mu \mathrm{g}$ creatine kinase and $26.4 \mathrm{~mm}$-sodium dithionite in a final volume of $1.0 \mathrm{ml}$ under $10 \% \mathrm{C}_{2} \mathrm{H}_{2}$ in Ar. The bottles were shaken for $1 \mathrm{~h}$ at $30^{\circ} \mathrm{C}$, and $0.5 \mathrm{ml}$ gas samples, which were replaced by $\mathrm{Ar}$, were analysed for $\mathrm{C}_{2} \mathrm{H}_{2}$ and $\mathrm{C}_{2} \mathrm{H}_{4}$ at $15 \mathrm{~min}$ intervals. The ATP-dithionite-dependent specific $\mathrm{C}_{2} \mathrm{H}_{2}$-reducing activity in the Triton-treated sample taken from the control vessel was $45 \pm 1.6 \%$ of the glucose-supported specific activity in a similar sample before the Triton treatment (see Table 3). The use of $1 \%$ or $4 \%$ in place of $2 \%$ Triton resulted in a lowering of the ATP-dithionitedependent $\mathrm{C}_{2} \mathrm{H}_{2}$-reducing activity, whereas shortening $(30 \mathrm{~min})$ or lengthening $(4 \mathrm{~h})$ the time of treatment with $2 \%$ Triton was without effect.

\section{Results}

Inhibition of nitrogenase activity by $\mathrm{O}_{2}$

Diazotrophic populations were grown either in anaerobic glucose-limited or in $\mathrm{O}_{2}$-limited chemostats (Hill, 1976a) and, consistent with this earlier work, the biomass was about $25 \%$ higher in the latter culture (see Methods). The anaerobic glucose-supported $\mathrm{C}_{2} \mathrm{H}_{2}$-reducing activity in samples from either culture was linear over $2 \mathrm{~h}$ in the presence of tetracycline $\left(40 \mu \mathrm{g} \mathrm{ml}^{-1}\right)$ (Fig. 2) and the specific activity of both cultures was similar (see Methods). No anaerobic $\mathrm{C}_{2} \mathrm{H}_{2}$-reducing activity was detected in the absence of glucose (data not shown). When glucose-supplemented samples from either culture were exposed to a DOC of $1.5 \mu \mathrm{M}$ no $\mathrm{C}_{2} \mathrm{H}_{2}$ reduction occurred (data not shown).

\section{Reversibility of the $\mathrm{O}_{2}$ inhibition of nitrogenase activity}

The complete inhibition by $\mathrm{O}_{2}$ of nitrogenase activity in glucose-supplemented samples from an anaerobic glucose-limited chemostat was partially reversible in the presence of $100 \mu \mathrm{g}$ chloramphenicol ml $\mathrm{m}^{-1}$ (Hill, 1976a). However, we found that under our assay conditions chloramphenicol only partially inhibited protein synthesis, whereas $40 \mu \mathrm{g}$ tetracycline $\mathrm{ml}^{-1}$ was completely effective without influencing nitrogenase activity (see Methods). Therefore tetracycline was used in the experiments described below.

Samples from the glucose-limited $\mathrm{N}_{2}$-fixing chemostat were introduced into the oxystat and control vessel, both of which contained glucose and tetracycline. After the initial anaerobic $\mathrm{C}_{2} \mathrm{H}_{2}$ reducing-activity had been measured in both vessels the sample in the oxystat vessel was exposed to a maintained DOC of $6 \mu \mathrm{M}$ for $20 \mathrm{~min}$ (Fig. 2). The control sample was exposed to $\mathrm{N}_{2}$. When the $\mathrm{O}_{2}$-treated sample was returned to anaerobic conditions, activity recovered without a lag to $58 \%$ of that in the anaerobic control (Figs 2 and 3). Therefore we conclude that in the absence of de novo protein synthesis, the inhibition of nitrogenase activity by $\mathrm{O}_{2}$ is reversible.

The addition of $60 \mathrm{~mm}$-glucose to samples from the anaerobic glucose-limited chemostat culture increased the rate of $\mathrm{O}_{2}$ uptake 1.6-fold (Hill, 1976a). Thus $\mathrm{O}_{2}$ exposure in the absence rather than in the presence of 


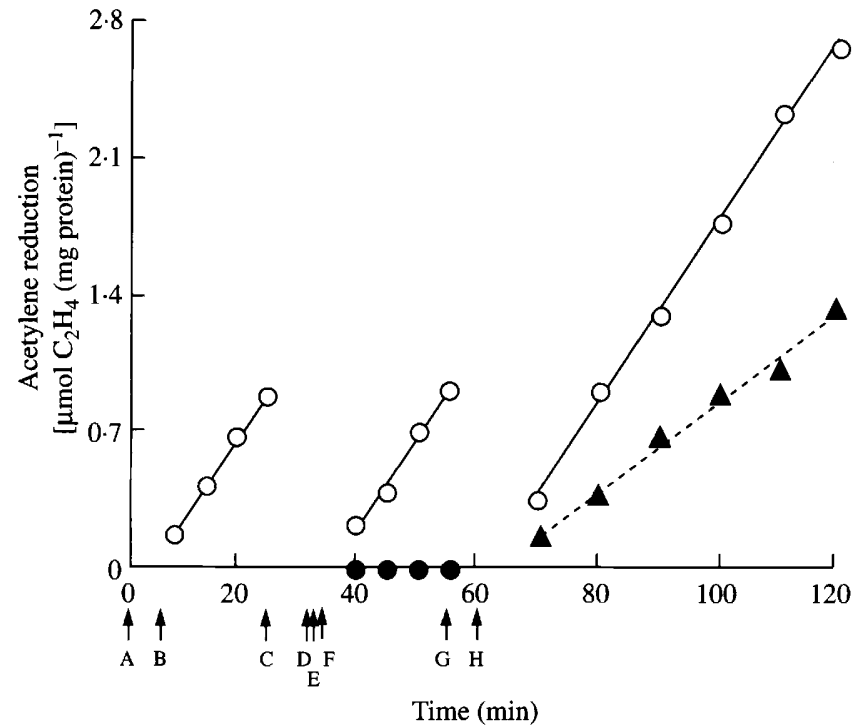

Fig. 2. Time course of a typical experiment illustrating the partial reversibility of the complete $\mathrm{O}_{2}$ inhibition of nitrogenase activity. Culture samples were introduced under $\mathrm{N}_{2}$ into the oxystat and control vessels (at $\mathrm{A}$ : see Methods), both of which contained tetracycline and glucose. $\mathrm{C}_{2} \mathrm{H}_{2}$ was injected at $B$ and $\mathrm{C}_{2} \mathrm{H}_{2}$-reducing activity was monitored in both vessels $(O)$. The cultures were sparged with $\mathrm{N}_{2}$ (between $\mathrm{C}$ and $\mathrm{D}$ ). Air was introduced to the oxystat at $\mathrm{E}$ to achieve a DOC of $6 \mu \mathrm{M}$, followed by the injection of $\mathrm{C}_{2} \mathrm{H}_{2}$ to both vessels $(\mathrm{F})$. $\mathrm{C}_{2} \mathrm{H}_{2}$-reducing activity was monitored in the oxystat $(O)$ and control (O) vessels for $20 \mathrm{~min}$, then both vessels were sparged with $\mathrm{N}_{2}$ (between $\mathrm{G}$ and $\mathrm{H}$ ). $\mathrm{C}_{2} \mathrm{H}_{2}$ was injected into both vessels at $\mathrm{H}$ and $\mathrm{C}_{2} \mathrm{H}_{2}$-reducing activity was measured over a further $1 \mathrm{~h}$ in the oxystat $(\boldsymbol{\Delta})$ and control (O) vessels. To provide sufficient $\mathrm{O}_{2}$ to maintain a DOC of $6 \mu \mathrm{M}$ for $20 \mathrm{~min}$ in a glucose-supplemented $20 \mathrm{ml}$ sample from the anaerobic glucose-limited population with a potential $Q_{\mathrm{O}_{2}}$ of $299 \pm 40 \mathrm{nmol}$ (mg protein) ${ }^{-1} \mathrm{~min}^{-1}$, the $66 \mathrm{ml}$ head space of the oxystat vessel was flushed for $2 \mathrm{~min}$ with air flowing at $50 \mathrm{ml} \mathrm{min}^{-1}$.

glucose might lead to a lower return of activity after the removal of $\mathrm{O}_{2}$. Samples from the glucose-limited population were exposed for $20 \mathrm{~min}$ to a maintained DOC in the absence or in the presence of glucose. The subsequent levels of activity returning after the removal of $\mathrm{O}_{2}$ were the same. This experiment was performed with three different DOCs $(6,48$ or $96 \mu \mathrm{M})$, and in each case the presence of glucose during $\mathrm{O}_{2}$ exposure made no difference to the level of nitrogenase activity returning (Table 2). Thus, a moderate change in the rate of $\mathrm{O}_{2}$ consumption during $\mathrm{O}_{2}$ treatment apparently does not affect the mechanism protecting nitrogenase activity from irreversible $\mathrm{O}_{2}$ damage.

To determine whether the DOC during $\mathrm{O}_{2}$ exposure influenced the level of nitrogenase activity returning after the removal of $\mathrm{O}_{2}$, samples were exposed to a range of DOCs $(1 \cdot 5-1200 \mu \mathrm{M})$ for $20 \mathrm{~min}$. The anaerobic activity after $\mathrm{O}_{2}$ treatment, compared to that of the anaerobic control (the degree of reversible $\mathrm{O}_{2}$ inhibition), never equalled $100 \%$, even following exposure to the lowest DOC examined (1.5 $\mu \mathrm{M})$ (Fig. 3). The percentage re-
Table 2. Influence of the duration of $\mathrm{O}_{2}$ exposure, in the presence or absence of $60 \mathrm{~mm}$-glucose, on the reversibility of nitrogenase activity

Data were derived from at least three experiments under each condition shown.

\begin{tabular}{|c|c|c|c|}
\hline \multirow[b]{2}{*}{$\begin{array}{c}\text { DOC } \\
(\mu \mathrm{M})\end{array}$} & \multirow{2}{*}{$\begin{array}{l}\text { Duration of } \\
\text { exposure } \\
\text { (min) }\end{array}$} & \multicolumn{2}{|c|}{ Degree of reversibility $(\%)^{*}$} \\
\hline & & $\begin{array}{l}\text { Glucose } \\
\text { present }\end{array}$ & $\begin{array}{l}\text { Glucose } \\
\text { absent }\end{array}$ \\
\hline 6 & $\begin{array}{l}15 \\
20 \\
40\end{array}$ & $\begin{array}{c}\text { ND } \\
58 \cdot 0 \pm 3 \cdot 0 \\
30 \cdot 0 \pm 1 \cdot 0\end{array}$ & $\begin{array}{l}77 \cdot 4 \\
57 \cdot 0 \pm 3 \cdot 0 \\
\quad \mathrm{ND}\end{array}$ \\
\hline 48 & $\begin{array}{l}10 \\
20\end{array}$ & $\begin{array}{l}47 \cdot 8 \pm 2 \cdot 0 \\
32 \cdot 0 \pm 3 \cdot 0\end{array}$ & $\begin{array}{l}51 \cdot 0 \pm 2 \cdot 0 \\
38 \cdot 0 \pm 1 \cdot 0\end{array}$ \\
\hline 96 & $\begin{array}{l}15 \\
20\end{array}$ & $\begin{array}{l}30 \cdot 8 \pm 2 \cdot 0 \\
25 \cdot 0 \pm 2 \cdot 0\end{array}$ & $\begin{array}{c}\mathrm{ND} \\
26 \cdot 0 \pm 2 \cdot 0\end{array}$ \\
\hline
\end{tabular}

ND, Not determined.

* The activity of the anaerobic (glucose-supplemented) control, taken as $100 \%$, was $61 \cdot 8 \pm 2 \cdot 0 \mathrm{nmol} \mathrm{C}_{2} \mathrm{H}_{4}(\mathrm{mg} \text { protein })^{-1} \mathrm{~min}^{-1}$ (mean $\pm \mathrm{SD}, n=11$ ).

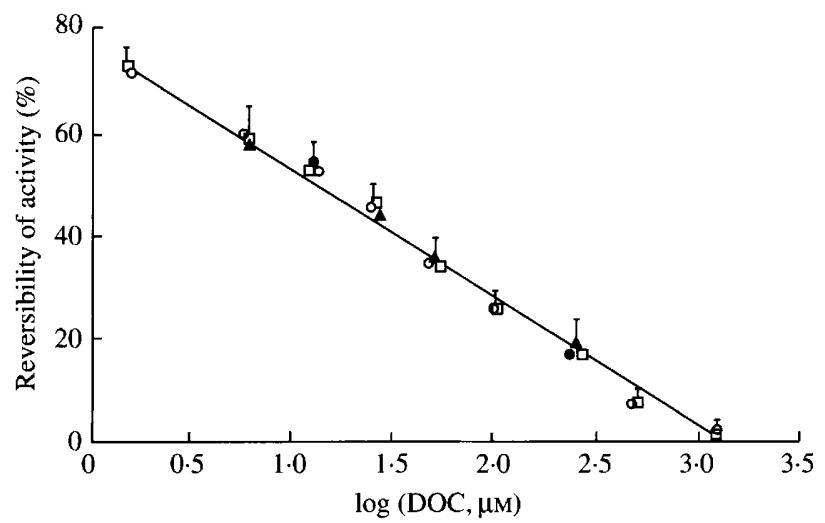

Fig. 3. Relationship between $\log \mathrm{DOC}$ and percentage reversibility of nitrogenase activity. $\mathrm{C}_{2} \mathrm{H}_{2}$-reducing activity was measured in culture samples exposed to either $\mathrm{O}_{2}$ or $\mathrm{N}_{2}$ for $20 \mathrm{~min}$ as described in Fig. 2 and Methods. Samples from the anaerobic glucose-limited culture were exposed to $\mathrm{O}_{2}$ in the presence $(O)$ or absence $(\square)$ of glucose. Samples from the $\mathrm{O}_{2}$-limited culture were exposed to $\mathrm{O}_{2}$ in the presence of glucose $(\boldsymbol{\Delta})$. Samples from the anaerobic glucose-limited culture were exposed to $\mathrm{O}_{2}$ in the absence of glucose and then assayed with dithionite and ATP (O) after treatment to make the cells leaky as described in Methods. Error bars show the greatest deviation for all experiments for a particular log DOC. The coordinate for the abscissa has been displaced to improve clarity. The precise DOCs used were $1 \cdot 5$, $6,12,24,48,96,240,480$ and $1200 \mu \mathrm{M}$.

versibility decreased with increasing DOC. Over the range of DOCs examined there appeared to be a linear relationship between the percentage reversibility and $\log$ DOC (Fig. 3).

Hill $(1976 a)$ showed that a doubling of the time of exposure to air approximately halved the degree of apparent reversibility of $\mathrm{O}_{2}$ inhibition of nitrogenase activity. The effect of varying the length of exposure (10, $15,20$ or $40 \mathrm{~min})$ to a range of maintained DOCs $(6,48$ 
Table 3. Degree of reversibility of nitrogenase activity in whole and leaky cells following $\mathrm{O}_{2}$ treatment in the presence of $60 \mathrm{~mm}$-glucose

\begin{tabular}{cccccc}
\hline \hline $\begin{array}{c}\mathrm{O}_{2} \\
\text { treatment } \\
(\mu \mathrm{M})\end{array}$ & $\begin{array}{c}\text { Specific activity* } \\
\text { in whole cells } \\
\text { with glucose }\end{array}$ & $\begin{array}{c}\text { Specific activity* } \\
\text { in leaky cells } \\
\text { with } \\
\text { dithionite-ATP }\end{array}$ & $\begin{array}{c}\text { Relative activity } \\
\text { of leaky cells } \\
\text { compared to whole } \\
\text { cells }(\%)\end{array}$ & \multicolumn{2}{c}{$\begin{array}{c}\text { Degree of } \\
\text { reversibility }(\%) \dagger\end{array}$} \\
\hline 0 & $61 \cdot 8 \pm 2$ & 27.0 & $43 \cdot 7$ & Whole cells & Leaky cells \\
\hline 12 & $31 \cdot 5$ & 14.0 & $44 \cdot 4$ & $51 \pm 2 \cdot 0$ & NA \\
240 & 10.5 & 4.9 & 46.6 & $17 \pm 1 \cdot 0$ & $18.1 \pm 1.0$ \\
\hline \hline
\end{tabular}

NA, Not applicable.

* Specific activity $=\mathrm{nmol} \mathrm{C}_{2} \mathrm{H}_{4}$ produced $(\mathrm{mg} \text { protein })^{-1} \mathrm{~min}^{-1}$.

$\dagger$ Results are means $\pm \mathrm{SD}(n=3)$.

or $96 \mu \mathrm{M})$ was investigated. Consistent with Hill (1976a) we found that the degree of reversible $\mathrm{O}_{2}$ inhibition was decreased in response to a longer exposure to $\mathrm{O}_{2}$. However, the percentage reversibility was apparently not proportional to the duration of $\mathrm{O}_{2}$ exposure (Table 2).

In the earlier work (Hill, 1976a), where the DOC was not maintained, the return of activity following exposure to $\mathrm{O}_{2}$ was greater in samples from $\mathrm{O}_{2}$-limited than from glucose-limited nitrogen-fixing chemostats. Using maintained DOCs that completely inhibit nitrogenase activity, we compared percentage recovery of $\mathrm{C}_{2} \mathrm{H}_{2}$-reducing activity after exposure to $\mathrm{O}_{2}$ in glucose-supplemented samples from the $\mathrm{O}_{2}$-limited chemostat with those from the glucose-limited chemostat. Following treatments with 6,24 and $48 \mu \mathrm{M}-\mathrm{O}_{2}$ for $20 \mathrm{~min}$, the subsequent percentage recovery of anaerobic $\mathrm{C}_{2} \mathrm{H}_{2}$-reducing activity was the same in both types of culture samples (Fig. 3).

\section{Irreversible inhibition by $\mathrm{O}_{2}$ of nitrogenase activity}

To determine whether the electron donation system to nitrogenase in vivo is more sensitive to $\mathrm{O}_{2}$ than nitrogenase itself, it was necessary to bypass the natural electron donation system. This was achieved by making the cells leaky with Triton X-100, to enable sodium dithionite and ATP to enter in order to provide electrons for nitrogenase activity. Samples from the glucoselimited chemostat were exposed to a maintained DOC or anaerobiosis as shown in Fig. 2. Prior to the injection of $\mathrm{C}_{2} \mathrm{H}_{2}$ for the final measurement of anaerobic $\mathrm{C}_{2} \mathrm{H}_{2}$ reduction the contents of the control and oxygentreatment vessels were removed by syringe and the $\mathrm{C}_{2} \mathrm{H}_{2}$ reducing activity in whole and leaky cells was measured (see Methods). The treatment with Triton of samples removed from the anaerobic control vessel prevented glucose-supported $\mathrm{C}_{2} \mathrm{H}_{2}$-reducing activity. This indicated that the treatment had inactivated the natural supplies of ATP and reducing power. However, when sodium dithionite and ATP were added to the leaky cells, $\mathrm{C}_{2} \mathrm{H}_{2}-$ reducing activity was restored (Table 3 ). This activity was linear for $60 \mathrm{~min}$ and was $44 \pm 1 \cdot 6 \%$ of the activity of untreated samples supplied with glucose (Table 3). When ATP was provided without sodium dithionite no activity was detected (data not shown), indicating that dithionite was providing electrons for nitrogenase activity in leaky cells.

The anaerobic activity in intact cells supplied with glucose and in leaky cells supplied with ATP and sodium dithionite was measured after samples from the glucoselimited cultures had been treated with either 12 or $240 \mu \mathrm{M}-\mathrm{O}_{2}$ for $20 \mathrm{~min}$. The degree of reversibility of $\mathrm{O}_{2}$ inhibition compared to the anaerobic control was similar in whole and leaky cells (Table 3 ). Therefore, we conclude that the electron donation system to nitrogenase is no more $\mathrm{O}_{2}$ sensitive than nitrogenase itself.

\section{Discussion}

Our finding of complete inhibition of nitrogenase activity in samples exposed to a DOC of $1.5 \mu \mathrm{M}$ is consistent with the results of Hill et al. (1984), who found, using leghaemoglobin as the $\mathrm{O}_{2}$-sensor, almost complete inhibition by a DOC of $0.55 \mu \mathrm{M}$ in samples from sucrosegrown batch cultures of a derivative of strain M5a1 [UNF767(pRD1)] which carries a chromosomal nifH::lac fusion and the $\mathrm{Nif}^{+}$plasmid $\mathrm{pRD} 1$. However, Goldberg et al. (1987) reported that the $\mathrm{C}_{2} \mathrm{H}_{2}$-reducing activity in samples from glucose-grown batch cultures of $K$. pneumoniae (strain Kp1) was completely inhibited only when the DOC was $>5 \cdot 2 \mu \mathrm{M}$. The reason for these differences in the apparent sensitivity of nitrogenase activity to $\mathrm{O}_{2}$ may lie in the various strains or the growth conditions used.

To confirm the earlier observations (Hill, 1976a) that $\mathrm{O}_{2}$ inhibition of nitrogenase activity in $K$. pneumoniae can be reversible and to investigate the mechanisms that prevent $\mathrm{O}_{2}$-inactivation of nitrogenase activity we improved the methodology. Previously the DOC in assays for $\mathrm{C}_{2} \mathrm{H}_{2}$ reduction was neither measured nor maintained, and the inclusion of chloramphenicol in these assays was 
assumed to inhibit nitrogenase synthesis. In the present work a range of DOCs in culture samples during assays for acetylene reduction was achieved by using a purposebuilt oxystat and we established that, by replacing chloramphenicol with tetracycline to inhibit protein synthesis in these assays, the rapid synthesis of nitrogenase, which can occur following $\mathrm{O}_{2}$ removal (Cannon et al., 1985), does not contribute to the return of $\mathrm{C}_{2} \mathrm{H}_{2}$ reducing activity after $\mathrm{O}_{2}$ inhibition. Our results show that, after complete inhibition of nitrogenase activity by $\mathrm{O}_{2}, \mathrm{C}_{2} \mathrm{H}_{2}$-reducing activity returns under anaerobiosis without a lag. However, the amount of activity returning was never $100 \%$, even in culture samples exposed to the lowest DOC we could control $\left(1.5 \mu \mathrm{M} \mathrm{O}_{2}\right)$.

Goldberg et al. (1987) also reported reversible $\mathrm{O}_{2}$ inhibition of nitrogenase activity in $K$. pneumoniae. They observed that $80-90 \%$ of the initial anaerobic activity returned after $20 \mathrm{~min}$ exposure to either 1 or $5.3 \mu \mathrm{M}-\mathrm{O}_{2}$. In contrast, we obtained only $69 \%$ of the initial activity following a $20 \mathrm{~min}$ exposure to $1.5 \mu \mathrm{M}-\mathrm{O}_{2}$. This recovery dropped to $58 \%$ after a $20 \mathrm{~min}$ exposure to $6 \mu \mathrm{M}-\mathrm{O}_{2}$. Goldberg et al. (1987) apparently did not prevent de novo protein synthesis in their assays. Thus in addition to the possibility that their strain differed from ours, the greater recovery of activity in their experiments may have been due to some resynthesis of nitrogenase. On the other hand, their $\mathrm{O}_{2}$ treatments did not completely inhibit $\mathrm{C}_{2} \mathrm{H}_{2}$ reduction whereas ours did. Thus, the $\mathrm{O}_{2}$ concentration in vivo may have been lower in their experiments than in ours. Hence, less damage to nitrogenase may have taken place, which could account for their greater recovery of activity.

A diazotrophic glucose-limited chemostat population of $K$. pneumoniae can be 'trained' to use $\mathrm{O}_{2}$. This is achieved by gradually introducing $\mathrm{O}_{2}$ so that the DOC remains below that detectable on a galvanic $\mathrm{O}_{2}$ electrode (approximately $0.5 \mu \mathrm{M}-\mathrm{O}_{2}$ ). An increase in $\mathrm{O}_{2}$ supply resulting in detectable DOC indicates the subsequent washout of the culture (Hill, 1976a). During $\mathrm{O}_{2}$-limited steady-state diazotrophic growth the biomass is proportional to the partial pressure of supplied $\mathrm{O}_{2}$, so the organisms are probably carrying out a mixed fermentative and oxidative catabolism (Hill, 1976a). Hill (1976a) found that the percentage return of nitrogenase activity in samples from the $\mathrm{O}_{2}$-limited population was greater than that in samples from the anaerobic glucose-limited population. In contrast, we found no difference when the DOC was maintained during $\mathrm{O}_{2}$ treatment. The difference observed previously was probably due to the greater density of the $\mathrm{O}_{2}$-limited population causing a lower DOC during treatment. Hence, the changes in physiology associated with the use of $\mathrm{O}_{2}$ during diazotrophic growth apparently do not influence the process preventing $\mathrm{O}_{2}$ damage to nitrogenase.
In the obligately aerobobic Azotobacter spp. the complete inhibition of nitrogenase activity by $\mathrm{O}_{2}$ can be partially or fully reversible (Drozd \& Postgate, 1970). The degree of reversibility is independent of the DOC and the duration of $\mathrm{O}_{2}$ exposure but depends upon the DOC during growth (Dingler \& Oelze, 1985). The degree of reversibility in $A$. vinelandii is greater in organisms grown at a lower compared to a higher DOC (Dingler \& Oelze, 1985). On the other hand, we have shown that in $K$. pneumoniae the degree of reversibility is decreased upon an increase in either the DOC or the time of $\mathrm{O}_{2}$ exposure, and the degree of reversibility is independent of whether $\mathrm{O}_{2}$ is present during growth. These differences in behaviour of $A$. vinelandii and $K$. pneumoniae may reflect differences in the mechanisms protecting nitrogenase from $\mathrm{O}_{2}$ damage. In $A$. vinelandii the reversible inhibition of nitrogenase activity by $\mathrm{O}_{2}$ arises from the formation of an $\mathrm{O}_{2}$-tolerant complex involving the nitrogenase proteins and the $\mathrm{Fe}-\mathrm{S}$ protective protein (Haaker \& Veeger, 1977), whereas in K. pneumoniae no such protective protein or complex has been identified by using techniques employing immunology or chromatography (Hochman et al., 1987).

Goldberg et al. (1987) suggested that the reversibility of $\mathrm{O}_{2}$ inhibition of nitrogenase activity in $K$. pneumoniae could simply occur by changes in the direction of electron flow either to nitrogenase, under anaerobiosis, or to the respiratory chain when $\mathrm{O}_{2}$ is present. A potential candidate for the regulation of activity may be the post-translational modification of the nif-specific flavodoxin by the covalent attachment of coenzyme A (Thorneley et al., 1992). In addition, the diversion of electron flow within nitrogenase may occur, as Thorneley \& Ashby (1989) have shown that without loss of activity high concentrations of the Fe protein of $K$. pneumoniae nitrogenase can reduce $\mathrm{O}_{2}$ to $\mathrm{H}_{2} \mathrm{O}$ stoichiometrically. However, at concentration ratios of $\mathrm{Fe}$ protein to $\mathrm{O}_{2}$ of less than 4 they observed irreversible damage, possibly as a result of the production of $\mathrm{O}_{2}^{-}$. The property of reversibility implies that $\mathrm{O}_{2}$-sensitive sites remain anaerobic or $\mathrm{O}_{2}$-limited during the inhibition of activity. Our results show that $17-18 \%$ of the initial anaerobic nitrogenase activity returned after $20 \mathrm{~min}$ exposure to air-saturated medium $\left(240 \mu \mathrm{M}-\mathrm{O}_{2}\right)$ and activity was detected after $20 \mathrm{~min}$ exposure to $\mathrm{O}_{2}$ saturation $(1200 \mu \mathrm{M}$ $\mathrm{O}_{2}$ ). The existence of an $\mathrm{O}_{2}$ gradient of this magnitude between the medium and the $\mathrm{O}_{2}$-sensitive sites in vivo suggests that protein-protein interactions or conformational changes may be involved in regulating nitrogenase activity and preventing damage.

Electrons for nitrogenase activity in $K$. pneumoniae are supplied from pyruvate by the action of the very $\mathrm{O}_{2}$ sensitive nifJ product (pyruvate-flavodoxin oxidoreductase), and are then transferred to nitrogenase via the nif $F$ 
product, flavodoxin (Hill \& Kavanagh, 1980; NievaGomez et al., 1980; Shah et al., 1983; Deistung et al., 1985; Drummond, 1986; Wahl \& Orme-Johnson, 1987; Thorneley \& Deistung, 1988). Therefore we investigated whether the failure to obtain full return of anaerobic nitrogenase activity following exposure to $\mathrm{O}_{2}$ was due to impairment of the processes supplying electrons for nitrogenase activity rather than to damage of nitrogenase itself. Our experiments with leaky cells showed that after $\mathrm{O}_{2}$ treatment with either a low $(12 \mu \mathrm{M})$ or a high $(240 \mu \mathrm{M})$ DOC the subsequent anaerobic activity of nitrogenase in vivo was apparently not limited by the electron supply from pyruvate. Therefore the failure to obtain full return of activity is due to $\mathrm{O}_{2}$ damage of nitrogenase. These results also suggest that in vivo the nifJ product is not more $\mathrm{O}_{2}$ sensitive than the nitrogenase.

We thank Professor B. E. Smith and Dr M. G. Yates for critically reading the manuscript, and Mrs R. J. Foote and Dr J. Stamper for its preparation.

\section{References}

BERGERSEN, F. J. \& TURNER, G. L. (1979). Systems utilising oxygenated leghaemoglobin and myoglobin as sources of free dissolved $\mathrm{O}_{2}$ at low concentrations for experiments with bacteria. Analytical Biochemistry 96, 165-174

CANNon, F. C. (1980). Genetic studies with diazotrophs. In Methods for Evaluating Biological Nitrogen Fixation, pp. 367-413. Edited by F. J. Bergersen. Chichester: John Wiley.

Cannon, M., Hill, S., Kavanagh, E. \& Cannon, F. (1985). A molecular study of nif expression in Klebsiella pneumoniae at the level of transcription, translation and nitrogenase activity. Molecular and General Genetics 198, 198-206.

Deistung, J., Cannon, F. C., Cannon, M. C., Hill, S. \& Thorneley, R. N. F. (1985). Electron transfer to nitrogenase in Klebsiella pneumoniae: nifF gene cloned and the gene product, a flavodoxin purified. Biochemical Journal 231, 743-753.

Dingler, Ch. \& Oelze, J. (1985). Reversible and irreversible inactivation of cellular nitrogenase upon oxygen stress in Azotobacter vinelandii growing in oxygen controlled continuous culture. Archives of Microbiology 141, 80-84.

Drozd, J. \& Postgate, J. R. (1970). Effects of oxygen on acetylene reduction, cytochrome content and respiratory activity of Azotobacter chroococcum. Journal of General Microbiology 63, 63-73.

Drummond, M. (1986). Structure predictions and surface change of nitrogenase flavodoxins from Klebsiella pneumoniae and Azotobacter vinelandii. European Journal of Biochemistry 159, 549-553.

GoldberG, I., NADler, V. \& Hochman, A. (1987). Mechanism of nitrogenase 'switch off' by oxygen. Journal of Bacteriology 169, 874-879.

HAAKER, H. \& VEEGER, C. (1977). Involvement of the cytoplasmic membrane in nitrogen fixation by Azotobacter vinelandii. European Journal of Biochemistry 77, 1-10.

HILL, S. (1976a). Influence of atmospheric oxygen concentration on acetylene reduction and efficiency of nitrogen fixation in intact Klebsiella pneumoniae. Journal of General Microbiology 93, 335-345.

HiLl, S. (1976b). The apparent ATP requirement for nitrogen fixation in growing Klebsiella pneumoniae. Journal of General Microbiology 95, 297-312.
Hill, S. \& Kavanagh, E. (1980). Roles of nifF and nifJ gene products in the electron transport to nitrogenase in Klebsiella pneumoniae. Journal of Bacteriology 141, 470-475.

Hill, S., Turner, G. L. \& Bergersen, F. J. (1984). Synthesis and activity of nitrogenase in Klebsiella pneumoniae exposed to low concentrations of oxygen. Journal of General Microbiology 130, 1061-1067.

Hill, S., Viollet, S., Smith, A. \& Anthony, C. (1990). Roles for enteric $d$-type cytochrome oxidase in $\mathrm{N}_{2}$ fixation and microaerobiosis. Journal of Bacteriology 172, 2071-2078.

Hochman, A., Goldberg, I., Nadler, V. \& Hartmann, A. (1987). The mechanism of nitrogenase reversible 'switch off' by oxygen. In Inorganic Nitrogen Metabolism, pp. 173-174. Edited by W. R. Ullrich, P. J. Aparicio, P. J. Syrett \& F. Castillo. Berlin: Springer Verlag.

Johnson, M. J., Borkowski, J. \& Engelblom, C. (1964). Steam sterilisable probes for dissolved oxygen measurements. Biotechnology and Bioengineering 6, 457-468.

Kavanagh, E. \& Hill, S. (1990). The automatic maintenance of low dissolved oxygen using a photobacterial oxygen sensor for the study of microaerobiosis. Journal of Applied Bacteriology 69, 539-549.

Kelly, M. J. S., Poole, R. K., Yates, M. G. \& Kennedy, C. (1990). Cloning and mutagenesis of genes encoding the cytochrome $b d$ terminal oxidase complex in Azotobacter vinelandii. Mutants deficient in the cytochrome $d$ complex are unable to fix nitrogen in air. Journal of Bacteriology 172, 6010-6019.

Nieva-Gomez, D., Roberts, G. P., Klevickis, S. \& Brill, W. J. (1980). Electron transport to nitrogenase in Klebsiella pneumoniae. Proceedings of the National Academy of Sciences of the United States of America 77, 2555-2558.

Robson, R. L. \& Postgate, J. R. (1980). Oxygen and hydrogen in biological nitrogen fixation. Annual Review of Microbiology 34, 183-207.

Scherings, G., HaAker, H. \& Veeger, C. (1977). Regulation of nitrogen fixation by $\mathrm{Fe}-\mathrm{S}$ protein II, in Azotobacter vinelandii. European Journal of Biochemistry 77, 621-630.

Shah, V. K., Stacey, G. \& Brill, W. J. (1983). Electron transport to nitrogenase. Purification and characterisation of pyruvateflavodoxin oxidoreductase, the nifJ product. Journal of Biological Chemistry 258, 12064-12068.

SMith, A., Hill, S. \& ANTHONY, C. (1990). The purification, characterization and role of the $d$-type cytochrome oxidase of Klebsiella pneumoniae during nitrogen fixation. Journal of General Microbiology 136, 171-180.

TubB, R. S. \& PostGate, J. R. (1973). Control of nitrogenase synthesis in Klebsiella pneumoniae. Journal of General Microbiology 79, 103-117.

ThORNELeY, R. N. F. \& AshBY, G. A. (1989). Oxidation of nitrogenase iron protein by dioxygen without inactivation could contribute to high respiration rates of Azotobacter species and facilitate nitrogen fixation in other aerobic environments. Biochemical Journal 261, 181-187.

Thorneley, R. N. F. \& Deistung, J. (1988). Electron-transfer studies involving flavodoxin and a natural redox partner, the iron protein of nitrogenase. Conformational constraints on protein-protein interactions and the kinetics of electron transfer within the protein complex. Biochemical Journal 253, 587-595.

Thorneley, R. N. F., Abell, C., Ashby, G. A., Drummond, M. H., Eady, R. R., Huff, S., Macdonald, C. J. \& Shneier, A. (1992). Posttranslational modifications of Klebsiella pneumoniae flavodoxin by covalent attachment of coenzyme A, shown by ${ }^{31} \mathrm{P}$ NMR and electrospray mass spectrometry, prevents electron transfer from the nifJ protein to nitrogenase. A possible new regulatory mechanism for biological nitrogen fixation. Biochemistry 31, 1216-1224.

WAHL, R. C. \& ORME-Johnson, W. H. (1987). Clostridial pyruvate oxidoreductase and the pyruvate oxidising enzyme specific to nitrogen fixation in Klebsiella pneumoniae are similar enzymes. Journal of Biological Chemistry 282, 10489-10496. 